\title{
Land-and-Ecological Problems of Kuzbass Mineral Resources Development
}

\author{
Aleksander Solovitskiy ${ }^{1}$, Olga Brel $^{1, *}$, Anna Saytseva ${ }^{1}$, and Philipp Kaizer ${ }^{1}$ \\ ${ }^{1}$ Kemerovo State University, Department of Geology and Geography, 650000, Kemerovo, Krasnaya \\ Street, 6, Russia
}

\begin{abstract}
It is established that the problem of effective and rational land use for environmentally friendly development of mineral resources is that it is connected with only one goal - to ensure coal mining, after which no new sources of income are available. At the same time, the land use economy entirely depends on the legal regime of the land, which determines its reaction to the slightest changes in legislation. Modern models of efficient and rational land use for the environmentally friendly development of Kuzbass subsoil are not currently developed. Under the circumstances, there is a need to develop a comprehensive theory of such land use, aimed at ensuring sustainable development of the region. The justification of the principles and mechanism of management of the land fund of mining enterprises determines its effectiveness. Establishing the dependence of effective and rational land use for environmentally friendly subsoil development characterizes a new level of information interaction between sciences (land management, mining and economy). Practical application of this theory lies in effective subsoil use.
\end{abstract}

\section{Introduction}

The relevancy and unconditional priority of land use and ecology of mining enterprises in Kuzbass are connected, first of all, with the specific character of legal regime of lands, which is characterized by multidimensionality. Management and disposal mechanism of these lands is specific and based on the protection of interests of land users and the region, the introduction of payment for land use, close connection of land management and urban development [1-4]. The absence of such a mechanism at the end of the last century [5-7] in Kuzbass resulted in negative consequences: almost $50 \%$ decline in coal production, as well as the closure of more than 30 mines and open pits. The ineffectiveness of this approach to land use led to the fact that subsoil use in the region resulted in significant amount of disturbed land [8-12]. At present, about 36 thousand hectares of land have been disrupted in Kuzbass (in 2007 - 62,3 thousand hectares), of which more than 30 thousand hectares during the development of mineral deposits. Over the past three years, the area of disturbed land as a result of coal mining increased by 5.8 thousand hectares, while in the process of reclamation for the same period, restored 2.9 thousand hectares. The soil layer and

${ }^{*}$ Corresponding author: brel_o_a@mail.ru 
underlying rocks are completely destroyed in $40 \%$ of the territory. The main anthropogenic consequences of subsoil exploration are the following [13]:

- destruction of the fertile land layer;

- air pollution caused by emissions from mining equipment, industrial and municipal boiler houses, burning rock dumps;

- pollution of water bodies with mine, quarry, industrial and domestic wastewater;

- significant disruption of the terrain;

- exemption from land use, pollution and disturbance of land.

Despite the powerful recovery of coal mining in Kuzbass and the cardinal technical reequipment of mining enterprises, new models of efficient and rational land use for environmentally friendly development of subsoil resources have not been fully developed and poorly covered in the domestic scientific literature [3-7]. Consequently, the problem of developing the Kuzbass mineral resources lies in the fact that the increase in coal production should not contradict the modern legal field of rational and effective land use. The increase in coal production is associated with the creation of new coal mines and open pits, which causes an increase in the demand for land. Providing land for their establishment is a complex process, connected, first, with taking the land, secondly, with the registration of land title, thirdly, with the transfer of land from one category to another, and fourthly, with a paid land use. In this case, these land areas are provided after issuing the mineral land patent. The development of non-agricultural land use passes through the following stages: the preparation of an application, the agreement on the object location, land acquisition, the registration and issuance of documents for the right to use the land, and also the transfer of land to industrial and other special purposes. For the development of minerals, land plots are provided not only after registration of the mineral land patent, but also an approved remediation plan. In such enterprises, which provide a danger to the environment and a threat to the health of people, a sanitary protection zone which should be around mine workings, dumps and other sources of harmful dust and gas emissions is established.

\section{Materials and Methods}

The process of development the land plots for coal enterprises' construction in modern legal field is multifaceted. Land plot within the city is permissible to develop only in accordance with the Rules of land use and development of the settlement. Taking into account the town planning regulations and large built-up areas in populated areas, land plots for coal enterprises are located on the skirts of settlements, and more often beyond their borders. However, sometimes it is possible to transfer the land from one category to another, in practice the transfer from agricultural to industrial lands is most often carried out. When developing the land plots it is inadmissible to violate neighboring land tenure (land use), land with forest plantations. Such violations entail penalties, which are often quite costly. Enterprises of the coal industry cause more severe damage to neighboring land areas in connection with their production specifics and, in most cases, reclamation is required. The land plot should not only violate the borders of neighboring land plots, but also have an advantageous territorial position. In addition, it must ensure the safety of green plantations that are near the site being formed [14]. Land plots can be formed by merger, redistribution of land plots, division, and separation from land or from lands in state or municipal ownership. Most often, land plots are formed from state and municipal property, so the formation process is delayed for a long time.

For complex solution of the multifaceted problem of efficient and rational land use for the environmentally friendly development of Kuzbass subsoil, the authors propose the 
development of a theory that includes the basic principles of land use for non-agricultural purposes:

1. Redistribution of the balance of land to ensure revenues to budgets.

2. Organization of territory and ordering the land use.

3. Management of land payments.

4. Improvement of the ecological situation of the territory.

The land use for non-agricultural (mining) purpose includes:

- Area determination;

- Land plot arrangement;

- Establishment and coordination of borders.

The traditional approach to choosing the location of a land plot is based on the following criterion: $C v=\min$, where $C v$ is the cadastral value of the land plot.

In the authors' opinion, this approach does not fully reflect the solution of the problem of efficient and rational land use for the environmentally friendly development of Kuzbass subsoil; therefore, the following is suggested:

$$
\frac{B R}{B L} \geq 1
$$

where BR is receipts to the budgets from a land plot when a coal mining enterprise is put into operation;

$\mathrm{BL}$ is receipts to the budgets from the requested land before the allotment for the construction of such an enterprise.

The indicated revenues to the budgets $B$ are proportional to the area of the land fund they occupy and have the following form:

$$
B=k_{i} \times C_{i} \times P_{i}
$$

where $k_{i}$ is the coefficients; $C_{i}$ is tax rates.

At the same time, it should be taken into account that the requested lands for the construction of a coal mining enterprise has a complex differentiation according to the forms of ownership, land users and land categories (Table 1).

Some mining enterprises (Kedrovsky open pit, Vakhrushevsky open pit, the Ruban mine, and many others) are characterized by such complex classification of the land fund.

Table 1. Land classification by the example of open pit Mine field "Maiskaya".

\begin{tabular}{|l|c|l|}
\hline \multicolumn{1}{|c|}{ The name of land user } & Area, ha & \multicolumn{1}{|c|}{ Land category } \\
\hline $\begin{array}{l}\text { LLC Shakhtoupravlenie } \\
\text { "Mayskoye" }\end{array}$ & 1253.91 & $\begin{array}{l}\text { Agricultural lands } \\
\text { Lands for industry and other } \\
\text { special purposes }\end{array}$ \\
\hline Individuals & 169.76 & Agricultural lands \\
\hline OJSC "SUEK-Kuzbass" & 77.98 & $\begin{array}{l}\text { Lands for industry and other } \\
\text { special purposes }\end{array}$ \\
\hline LLC "Topkoe" & 43.82 & Agricultural lands \\
\hline LLC "Energetic open pit" & 120.12 & $\begin{array}{l}\text { Lands for industry and other } \\
\text { special purposes }\end{array}$ \\
\hline $\begin{array}{l}\text { Municipal property } \\
\text { management committee of } \\
\text { Prokopyevsky district }\end{array}$ & 1205.42 & Agricultural lands \\
\hline $\begin{array}{l}\text { Committee for the } \\
\text { administration of state } \\
\text { property of the Kemerovo } \\
\text { region }\end{array}$ & 539.65 & Agricultural lands \\
\hline LLC "Globus" & 67.78 & Lands for industry and other \\
\hline
\end{tabular}




\begin{tabular}{|l|c|l|}
\hline & & special purposes \\
\hline LLC "Direct-C" & 55.76 & $\begin{array}{l}\text { Lands for industry and other } \\
\text { special purposes }\end{array}$ \\
\hline $\begin{array}{l}\text { CJSC Mine office } \\
\text { "Perspectivnoe" }\end{array}$ & 774.68 & Agricultural lands \\
\hline $\begin{array}{l}\text { Forestry Department of the } \\
\text { Kemerovo Region }\end{array}$ & 35.94 & Forest lands \\
\hline
\end{tabular}

The boundaries of the considered land plots are also affected by the sanitary protection zones provided for them. They can be either stipulated by sanitary regulations and standards, or calculated ones, which must be approved. When forming land plots, it is possible to reduce the allocated area of a land plot in connection with an inadequate sanitary protection zone (SPZ). In such case the site is either reduced by area, establishing normative or calculated and approving it in the relevant authorities. This method often allows not reducing the necessary land area, but staying within the necessary boundaries while not harming the environment. The "Listvyazhnaya" mine develops underground coal reserves and, in accordance with sanitary regulations and standards 2.2.1/2.1.1.1200-03, belongs to the III hazard class with a standard SPZ size equal to $300 \mathrm{~m}$. The main sources of pollutant emissions into the atmosphere are located on several mine sites; therefore, the size of the normative SPZ is assigned as follows:

- The main industrial site of Block No. 1 is equal to $300 \mathrm{~m}$ from polluting sources;

- Joint boundary of SPZ for the industrial sites of Block No. 2, the vertical air shaft of Block 1 and the gas-drainage unit of Unit No. 1 with a size is equal to $300 \mathrm{~m}$;

- The site of the existing boiler house is equal to $50 \mathrm{~m}$ from pollution sources;

- The site of sewage treatment plants of domestic sewerage with a capacity of $600 \mathrm{~m} 3$ per day is equal to $200 \mathrm{~m}$.

The size of these normative SPZ is verified by:

1. Calculations of dispersion taking into account the background - calculated contamination zones (isolines equal to the maximum permissible concentration) are not obtained by any ingredient and summation.

2. Calculations of the levels of sound impact on housing - the over-standard effect of noise on housing is absent.

The boundaries of the sanitary protection zone of the "Listvyazhnaya" mine are not populated.

The organization of the territory is its arrangement, bringing it into a certain state for the realization of specific goals. Classification of the territory organization includes a set of elements that are divided into two groups. The first group includes land plots, borders, and territorial zones, and the second - the elements of their infrastructure. As an example the highways, railways, power lines and communications can be mentioned. The leading method of planning the territory organization in the authors' opinion is zoning. Zoning of the open pit "Korchakolsky" includes:

- open mining;

- internal dump;

- external heap;

- treatment facilities;

- roads;

- power line VL-6 kV;

- drainage area;

- motor vehicle section.

The ordering of land uses is to minimize the consequences of mining, which is assessed on the basis of the composition and value of land. 
The development of mines and open pits always affects the soil of the territory on which their location and mining of mineral resources are planned, which leads to its partial or complete destruction with all consequences [14]. In addition, the vegetative and animal world of the territory is subject to change, as well as all soil-and-ecological functions in the natural environment. The mining impact on land is divided into two types. The first type includes impacts that lead to disturbance of the soil cover, changes in the situation and relief, construction of infrastructure facilities, which leads to the formation of a new manmade landscape in the zone affected by mining. The second type includes impacts that lead to a deterioration in the quality of land and groundwater, the environment of plant growth and the habitat of animals, which can cause degradation of the natural landscape. In general, the following problems characterizing the impact on individual natural components and natural complexes of the studied area are emphasized:

- biotic;

- geological and geomorphological;

- climatic;

- landscape;

- pyrogenic;

- soil.

For example, the current state of the soil cover on the territory of open pit "Vakhrushevsky" is characterized by the complete destruction of the natural soil cover within the mining zone. Currently, the soil cover of the land area of 1522 hectares used for its development is completely broken. The disturbed natural soil cover of the pit is represented by various technogenic formations (technogenic soils), which is typical for landscapes with a high anthropogenic load. According to the classification of man-made soils, they belong to the class - transformational embryosomes, type - techno-typical. The studied territory of open pit "Kedrovsky" according to soil-geographical zoning is located at the boundary of two soil-geographical regions: the Mariinsk-Achinsk soil region of the dissected forest-steppe and forest-steppe foothills and on the boundary of the "island" forest-steppe and forest-steppe boundary of Kuznetsk Basin. The natural soil cover of the territory before its disruption by mining operations was represented by the following types of soils and their complexes: dark gray forest soils, black-earth leached by low-power medium-humus heavy-loamy in a complex of $25 \%$ with meadow black-earth alkaline soils subject to water and wind erosion, on low relief elements slopes of gullies and gullies in the natural relief were formed meadow heavy loamy soils. The soils listed above, formed in natural-historical conditions, currently occupy separate areas with undisturbed natural soil cover on the adjacent territory to the cut. Genetically, these soils had high soil fertility.

The main type of impact of a mining enterprise on the state of the soil cover is pollution by its emissions of contaminators, its violation, changes in the regime of underground waters in the zone of influence of mining operations and in adjacent territories. The negative impact on soils can be manifested in the change in the nature of land use in the territory of the enterprise, in changing its relief due to the development of overburden and mining operations, and the parameters of the hydrological regime. The soil provides the following functions: biosphere, inter-land, inland landscape, intra-soil. Their interrelation provides an impact on the environment violating one of them. With such an impact, the first to be violated is the subsoil functions, such as: physical, water-physical, water and gasregulating ability of the soil, provision of soil with nutrients (soil fertility), its sanitary and hygienic characteristics.

\section{Results and Discussion}


The introduction of paid land use has opened the possibility of using the economic regulation of land relations. Specificity of this problem is its interdependence with the legal regime of lands granted for the purposes of subsoil use which provides the necessity of its more detailed study to ensure the management of land payments. Subsoil users are usually in the situation when there is no single land use; moreover, the land plots for offices are located on the land of settlements and on the right of ownership, and mining (licensed) plots outside these settlements and more often on the right of lease. Therefore, a typical picture is a dilemma: the choice of ownership or lease. The authors propose the basic principle of such management of land payments, based on the following criteria: $L p=\min$, where $L p$ is land payments.

The main principle of a new approach to the implementation of land relations is the rational use and protection of land as the basis for improving the ecological situation of the territory for the life and activities of the population. Specificity of the legal regime of lands granted for purposes of subsoil use, special conditions for the return of these lands to economic circulation. Formed land plots are used on the right of lease, at the end of which the land plot should be reclaimed and handed over to the owner. In addition, when designing sites for coal enterprises, it is necessary to provide the prevention of erosion. It is necessary to timely and qualitatively carry out soil protection measures (technical and biological reclamation of soil). Reclamation of land and implementation of measures to prevent erosion processes are necessary means of protecting the environment. To implement the reclamation of disturbed territories, the authors propose an economic approach to solving this problem, which is based on the following criterion reflecting the maximum increase in the cadastral value: $\Delta C v=\max$.

Currently, the traditional approach is in effect, for example, after finishing the coal seams of CJSC "Kuzbassrazrezugol", "Vakhrushevsky" and "Kedrovsky" open pits the following operations will be carried put on their territories: the excavations and embankments are eliminated; the cloughs are covered or flattened; planning works are performed; remediation of disturbed territories is carried out. The planning of the territory is carried out at the expense of positive relief forms, having elevated marks. The main measures of land protection and rational use of the soil layer include: monitoring observations of changes in its condition; restoration and improvement of the territory; strict control of emissions of pollutants into the atmosphere and soil [15].

\section{Conclusions}

Based on the results of the studies, the authors developed a theory that determines the basis for effective and rational land use for environmentally friendly development of mineral resources, and the following conclusions are made:

1. It is established that modern models of efficient and rational land use for the environmentally friendly development of Kuzbass subsoil are not developed; this problem is poorly covered in the scientific literature.

2. It is shown that the economy of modern land use in Kuzbass entirely depends on the legal regime of the land, which determines its sensitivity to the slightest changes in legislation.

3. An economic mechanism for managing the land fund of mining enterprises has been developed.

4. It is shown that efficient and rational land use for ecologically clean development of Kuzbass mineral resources is a multifaceted problem, for the implementation of which a systematic approach based on the integration of a number of sciences is needed. 


\section{References}

1. M. Aien, A. Kalantari, I. P. Rajabifard D. Williamson, Developing and testing a 3D cadastral data model a case study in Australia (Spatia, Melbourne, 2012)

2. H. Mattsson, Real estate contracts in Northern Europe. Sustainability and balance if interests (HHAD, Zurich, 2011)

3. Real Property Formation Act (Hogskolan, Stockholm, 1998)

4. Swedish land and Cadastral Legislation (Kungl Tekniske Hogskolan, Stockholm, 1998)

5. K. Gawroński, K. Van Assche, J. Hernik, Infrastructure and Environment, 11, 53-70 (2010)

6. N. Mattsson, C-G. Hagander, En handbok om nya PBL och samhällsbyggande (AB, Svensk Byggtjänst, 2011)

7. D. Leonard, Land Administration in New South Wales. Study tour Russian LARIS Project Team. - Dep. of Land and Water Conservation ( NSW, Melbourne, 2001)

8. H. Molotch, Amer. J. Sociol. 82:2, 309-332 (1976)

9. R. Park, Human communities; the city and human ecology (Free Press, Glencoe, 1952)

10. B.W. Cowan, R.A. Logan, Rebuilding the cadastre in the Czech Republic: The challenges that lie ahead (CGIS, Ottawa, 1994)

11. A. Monashe, Urb. Des. Int. 18:1, 801-912 (2013)

12. G. Valnour, Eur. Plan. Stud. 23:1, 108-115 (2015)

13. A. Haase, D. Rink, K. Grossmann, M. Bernt, V. Mykhnenko, Env. Plan. 46, 1519-1534 (2014)

14. A. Solovitskiy, O. Brel, N. Nikulin, E. Nastavko, T. Meser, E3S Web of Conferences, 21, 02012 (2017)

15. F.W.M. Vera, Ecology and forest history (CABI Publishing, Oxon, 2000) 